\title{
Introduction to the Comprehensive Biodiversity Survey of Bukit Timah Nature Reserve, Singapore, 2014-2018
}

\author{
L. Chan ${ }^{1} \&$ G.W.H. Davison ${ }^{2}$ \\ ${ }^{1}$ International Biodiversity Conservation Division, National Parks Board, \\ 1 Cluny Road, 259569 Singapore \\ Lena_Chan@nparks.gov.sg \\ ${ }^{2}$ National Biodiversity Centre, National Parks Board, \\ 1 Cluny Road, 259569 Singapore
}

\begin{abstract}
We introduce the Comprehensive Biodiversity Survey of Bukit Timah Nature Reserve, Singapore, for which planning began in 2014, field work was conducted largely in 2015-2016, and results analysed and written up in 2017-2018. The comprehensive survey is placed in the context of previous surveys in 1991-1992 and in 1992-1997. Bukit Timah is historically important and continues to be nationally and internationally significant for nature conservation.
\end{abstract}

Keywords. Conservation, monitoring, protected areas, coastal hill dipterocarp forest

\section{Introduction}

Bukit Timah Nature Reserve (BTNR) has a special place in the national identity, natural history and cultural history of Singapore. The highest point in Singapore, measuring $163.6 \mathrm{~m}$ above sea level, lies within the legally gazetted 163 ha of the nature reserve. The richness of the biodiversity in BTNR had been recognised even in the nineteenth century, but in 1883 it was noted that there was no legal protection of forests: "There are in Singapore absolutely no Forest Rules or Regulations, or Forest law of any kind" (Cantley, 1883). To address this gap, eight forest reserves were identified by 1884 and "The demarcation of the Bukit Timah reserve was one of the first works that occupied my attention" (Cantley, 1885). As a result, the area now designated as a nature reserve has been protected longer than any other site in Singapore. The specimens that Alfred Russel Wallace spent several months collecting in Singapore, in particular in the vicinity of the present-day Bukit Timah Nature Reserve, between 1854 and 1856 (Wallace, 1869), contributed to the formulation of his ideas, on evolution with Charles Darwin and on global biogeography including the delineation of Wallace's Line (Wallace, 1876), both of which form the bedrock of modern biology and ecology. One of the oldest trees in Singapore stands in the grounds of BTNR (Lum \& Sharp, 1996). More than 50\% of Singapore's indigenous plant species have been recorded in BTNR which constitutes around $0.23 \%$ of Singapore's land area (Ho et al., 2019). This attests to its critical importance for conservation of the national flora. The results of the faunal surveys 
published in this volume also illustrate high animal diversity (Fig. 1A-C). Despite dense urbanisation in the vicinity of BTNR, and the high number of people visiting BTNR, its biodiversity, discovery of new species, new records and re-discovery of species previously thought to be locally extinct continue to surprise us.

The flora and fauna of BTNR have been well researched and documented, from 1854 until the present day (Chin et al., 1995; Chan \& Corlett, 1997; Henderson, 2000; LaFrankie et al., 2005). Nevertheless, this Comprehensive Biodiversity Survey of Bukit Timah Nature Reserve (BTNR), coordinated by the National Parks Board (NParks) in partnership with experienced naturalists, academics and the private sector, is unique in many ways. Firstly, it is the only coordinated holistic survey that focuses entirely on BTNR, covering a broad scope, including flora, fauna, fungi, as well as the physical characteristics, mapping of streams, genomics, etc., over a defined time period. Secondly, all researchers were issued a grid map so that sampling plots and transects could be charted in a uniform way across all the studies. Thirdly, a survey frame was shared with the researchers so that data could be collected systematically for long-term monitoring and comparative analyses. Fourthly, field methodologies were submitted to the Secretariat for concurrence, in order to facilitate scheduling and improve coordination between studies. Fifthly, this establishes a pattern of regular surveys that could be repeated at intervals of about 20 years, since the previous survey in 1993-1997.

\section{Previous surveys}

1991-1992 survey

One of the earliest activities initiated by the National Parks Board, after its formation in 1990, was a physical and biological survey of BTNR, focussing particularly on the flora. Some field surveys were conducted from March to July 1992, with unpublished reports covering the physiography (Gupta, 1992), flora (Turner et al., 1992), insects, amphibians and reptiles (Yang et al., 1992), and birds and mammals (Kang, 1992). A detailed report was also prepared by Murphy (1993) covering the streams as well as various groups of invertebrates in both BTNR and the Central Catchment Nature Reserve (CCNR). Copies of the unpublished reports are kept in the National Biodiversity Centre, Singapore. The reports provide important baseline information, for example stream maps and preliminary lists of dragonflies, butterflies and grasshoppers.

\section{5 compilation on flora and fauna of BTNR}

In 1995 the National Parks Board published a Supplement to the Gardens' Bulletin Singapore (Chin et al., 1995) that included 15 chapters, of which six were on plant and fungal groups: flowering plants (Corlett, 1995c), Rubiaceae (Tan et al., 1995), bryophytes (Wee \& Mohamed, 1995), pteridophytes (Wee, 1995a), algae (Wee, 1995b), and vesicular-arbuscular mycorrhizae (Louis, 1995); six on animal groups: mammals (Corlett \& Lucas, 1995), long-tailed macaques (Lucas, 1995), birds (Kang \& Hails, 1995), amphibians and reptiles (Chou, 1995), freshwater decapod crustaceans 


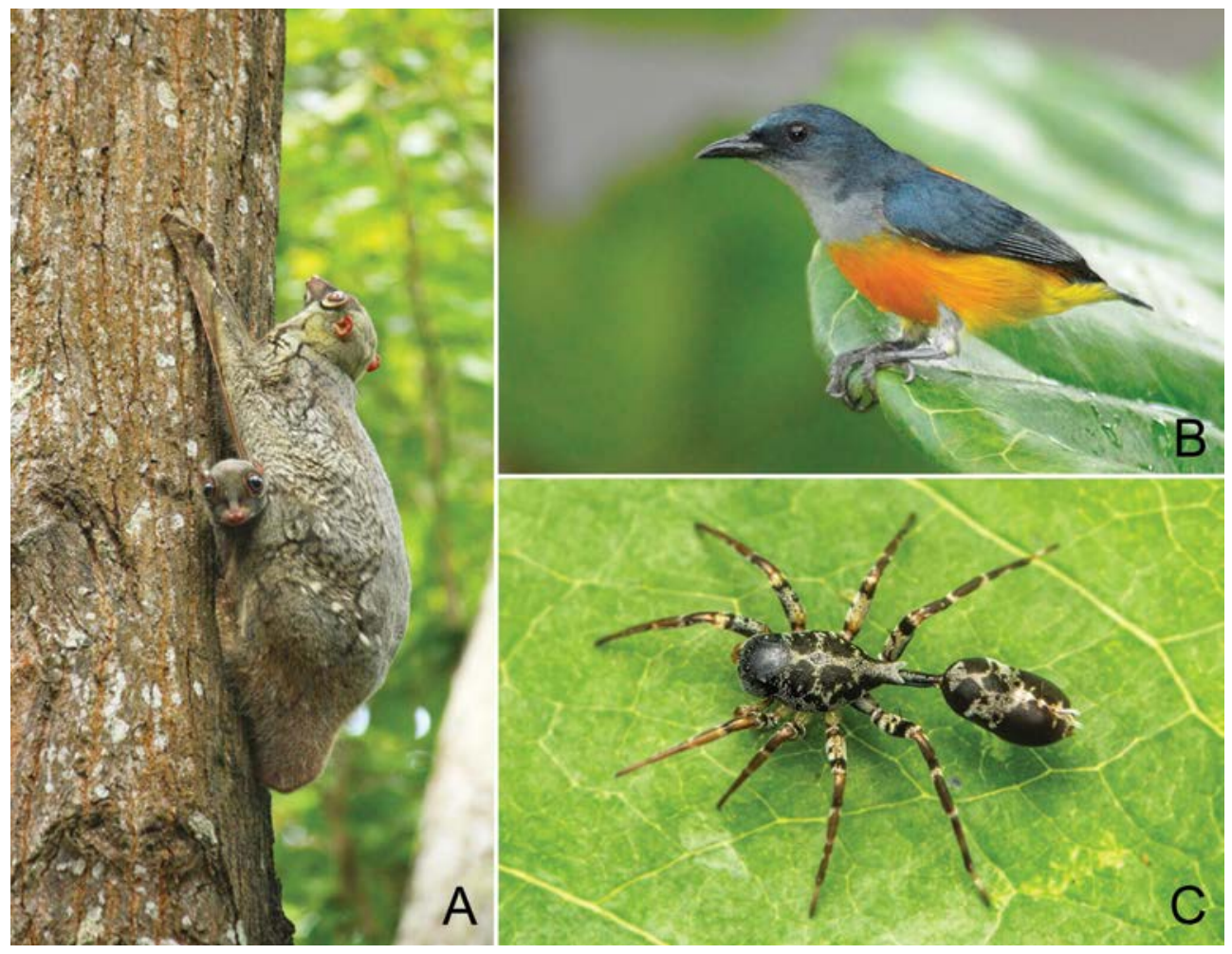

Fig. 1. A. The Malayan Colugo Galeopterus variegatus was sighted 141 times during this comprehensive survey in contrast to 39 records in the previous survey. B. The Orange-bellied Flowerpecker Dicaeum trigonostigma is one of the top 20 most abundant species recorded at Bukit Timah Nature Reserve both during the Comprehensive Biodiversity Survey and the Annual Bird Census 1997-2015 of the Bird Group, Nature Society Singapore. C. This is an Aetius species, an ant-mimic spider of the Corinnidae family. There are only three described species of Aetius in the world and this is not one of them. Therefore, it must be a new species to science. (Photos: A, S. Spykerman; B, Y. Cai; C, J.K.H. Koh).

(Ng, 1995), and fishes (Lim, 1995); with an introduction (Corlett, 1995a), history (Corlett, 1995b) and a review of BTNR's likely prospects (Corlett, 1995d). Some of the authors had conducted fieldwork over a considerable period, and the papers were predominantly based on the accumulated experience of expert individuals carried out independently rather than time-bound surveys of BTNR.

\section{2-1997 survey}

The coverage of the 1991-1992 Nature Reserves survey was extended to include both BTNR and the Central Catchment Nature Reserve, placing more emphasis on faunal surveys since the 1991-1992 surveys had already covered the flora and extending its time-frame to 1997. Consequently, though the total information collected was greater than the 1995 publication, it became difficult in some cases to distinguish between records for each of the two reserves. 
The survey was significant for several reasons. It covered a wide range of taxonomic groups. It was the first survey to be co-funded by private donors and government. It was a partnership involving the Nature Society Singapore (NSS), academics from local universities, keen amateur naturalists, government officers, and experts from overseas. The results were published as scientific papers in a special issue of the Gardens' Bulletin Singapore (Chan \& Corlett, 1997), giving access to biodiversity information that could be used to design science-based management plans for the Nature Reserves.

\section{Current survey}

\section{4-2018 survey}

Considering the interval of 20 to 25 years that had elapsed since the start and completion of the previous survey (1992-1997), NParks and the Nature Reserves Scientific Advisory Committee agreed in 2014 that it would be timely to initiate a further, more intensive and comprehensive survey, focusing on BTNR. Leading up to the official announcement of the Comprehensive Biodiversity Survey of BTNR on 14 February 2015, preliminary groundwork and preparatory planning had already begun in April 2014.

\section{Objectives}

The objectives of the Comprehensive Biodiversity Survey of Bukit Timah Nature Reserve were:

a. To collect baseline data through long-term survey and monitoring of the biological diversity within the nature reserve; and

b. To apply the data collected to the formulation of science-based management plans for the nature reserve, to ensure the persistence of the nature reserve into the future.

\section{Duration}

Planning work and approval of survey methodologies occupied the period from August to November 2014.

Most of the field surveys were carried out from December 2014 to December 2017. The period from January to June 2018 was available for analysis of results, writing and preparation for publication. Manuscripts were submitted to the editors for publication in the Gardens' Bulletin Singapore, to be launched in May 2019.

\section{Administration}

A secretariat was formed within the National Parks Board, consisting of Dr Lena Chan, Sharon Chan, Chew Ping Ting, Cheryl Chia, Ruth Tan, Samantha Lai, Dr Geoffrey Davison, Zhou Boyi, Lim Weihao, Li Tianjiao, Daniel Ng, Low Bing Wen 
and Holly Siow. The secretariat prepared an initial list of desirable and relevant survey topics and identified two or more group planners for each topic, one from the National Parks Board and one or more from other institutions. The tasks of the group planners included design, scoping, inputs to methods, and arranging implementation in the field. Each topic was assigned one coordinator from the National Parks Board, whose tasks were facilitation and logistics support. The group planners, coordinators and researchers are shown in Table 1.

Planning meetings were held in 2014 and invitations sent out. Group planners were encouraged to form teams to work on their particular group or topic. Several coordinating meetings and sharing sessions were organised to assist in the implementation of fieldwork and to address and resolve any field-based difficulties encountered. This comprehensive survey was co-funded by NParks and the Hongkong and Shanghai Banking Corporation Limited.

Areas and topics covered

The 2014-2018 survey focused specifically on BTNR. It was left to the discretion of each team whether to include the immediately adjacent parks (Hindhede Nature Park, Dairy Farm Nature Park, together with Singapore Quarry and Rifle Range Road), depending on context, relevance and the availability of time and manpower.

The vegetation zones within BTNR have been categorised by Wee (1964) and mapped by Wong et al. (1994), Metcalfe et al. (1998) and Corlett (1997). Four structural vegetation types were distinguished by Wong et al. (1994), using data from quadrats within the Central Catchment Nature Reserve. They were:

Type 1, early successional vegetation with only scattered trees;

Type 2, with many small-crowned trees $8-15 \mathrm{~m}$ tall;

Type 3, with taller, larger-crowned trees; and

Type 4, with some very large trees, structurally equivalent to primary forest.

Metcalfe et al. (1998) applied a similar but not identical classification to the forest vegetation of BTNR, including young secondary forest (roughly equivalent to Type 2), old secondary forest (equivalent to Type 3), and near-pristine forest and other primary forest (equivalent to Type 4). Metcalfe et al. (1998) described some of the floristic associations with the structurally defined forest types.

As there has been progressive maturation of the vegetation, particularly in the Nature Parks now adjacent to BTNR, the National Parks Board prepared an updated map of the vegetation zones in BTNR and its surroundings (Fig. 2). Type 1 (early successional vegetation) is no longer a significant component, leaving three main vegetation zones.

A list of taxa and topics requiring coverage was prepared. Individuals with interest and expertise were approached for each, with freedom to recruit for themselves a suitable team. Particular methods were left to each team as they are the experts in the taxonomic group, but some general guidelines and materials were given. These included: 
Table 1. Group planners, coordinators and researchers for the Comprehensive Biodiversity Survey of Bukit Timah Nature Reserve, Singapore.

\begin{tabular}{|c|c|c|}
\hline Topic & $\begin{array}{l}\text { Group planners and } \\
\text { coordinators }\end{array}$ & Researchers (in alphabetical order) \\
\hline Flora & $\begin{array}{l}\text { David Middleton \& Shawn } \\
\text { Lum } \\
\text { Coordinators: } \\
\text { Lua Hock Keong, Hassan } \\
\text { Ibrahim \& Ho Boon Chuan }\end{array}$ & $\begin{array}{l}\text { Ali, I., Athen, P., Bazilah, I., Chin, L.L., Daniel, D.C., } \\
\text { Farez, A., Fauzan, R., Hassan, I., Hew, A.I., Ho, B.C., } \\
\text { Khor, I., Koh, S.L., Lam, H.J., Lee, S., Leong, P., Lim, } \\
\text { F., Lim, R., Lim, W.H., Lindsay, S., Loo, A.H.B., } \\
\text { Low, W.T., Lua, H.K., Middleton, D.J., Nadya } \\
\text { Hamdan, Niissalo, M., Nurul Huda, A., Oon, C., } \\
\text { Puglisi, C., Saifuddin, S., Seah, W.W., Staples, G.W., } \\
\text { Tan, I., Tan, L.W.A., Tan, S.S.L., Tok, Y.X., Brigitte } \\
\text { de Wilde-Duyfjes, Willem de Wilde, Wong, S.H., } \\
\text { Yap, A., Yeo, R.S.W., Yeoh, Y.S., Yong, C., Yuen, C. }\end{array}$ \\
\hline Macrofungi & Serena Lee & $\begin{array}{l}\text { Aung Thame, Bazilah I., Christina Soh, Ho Boon } \\
\text { Chuan, Leong, P., Leong-Škorničková, J., Derek Liew, } \\
\text { Lua H.K., Middleton, D.J., Ng Xin Yi }\end{array}$ \\
\hline $\begin{array}{l}\text { Mammals, } \\
\text { reptiles and } \\
\text { amphibians }\end{array}$ & $\begin{array}{l}\text { Robert Teo, Subaraj } \\
\text { Rajathurai, Noel Thomas, } \\
\text { Kelvin Lim \& Nick Baker } \\
\text { Coordinators: } \\
\text { Cheryl Chia \& Holly Siow }\end{array}$ & $\begin{array}{l}\text { NParks: Benjamin Lee Chengfa, Benjamin Paul Lee, } \\
\text { Cheryl Chia, Cyrena Lin, Germaine Leng, Gloria } \\
\text { Seow, Holly Siow, Ivan Kwan, James Gan, Jacky Soh, } \\
\text { Jayasri Lakshminarayanan, Jeanne Tan, John Wei, } \\
\text { Joseph Lin, Leroy Alphonso, Lim Siew Hong, Mishak } \\
\text { Shunari, Mohd Azlin bin Sani, Robin Ngiam, Rushan } \\
\text { bin Abdul Rahman, Shirley Wong, Spykerman Shaun } \\
\text { Adam. HSBC: Carmen Choy, Casey Ng, Ernest Soh, } \\
\text { Esther Chow, Matt Chan, Ong Ya-Yi, Patrick Chong, } \\
\text { Shyamsundar Veeraraghavan, Steven Pereira. Others: } \\
\text { Amanda Tan, Angus Lamont, Audrey Lee, Chan Kwok } \\
\text { Wai, Cherry Goh, Chloe Tan, Claudia Tan, Fung Tze } \\
\text { Kwan, Gloria Seow, Jocelyn Yeo, Joey Gan, Joleen } \\
\text { Chan, Joys Tan, Law Ing Sind, Law Ingg Thong, Lee } \\
\text { Juin Bin, Lee King Li, Marcus Chua, Mary-Ruth Low, } \\
\text { Ng Bee Choo, Nick Baker, Rebecca Lee, Sankar } \\
\text { Ananthanarayanan, Serin Subaraj, Subaraj Rajathurai, } \\
\text { Tan Hui Zhen, Teresa Teo Guttensohn, Timothy Pwee, } \\
\text { Vilma D’Rozario, Yeo Suay Hwee }\end{array}$ \\
\hline Birds & $\begin{array}{l}\text { Geoffrey Davison \& Lim } \\
\text { Kim Seng } \\
\text { Coordinator: } \\
\text { Low Bing Wen }\end{array}$ & $\begin{array}{l}\text { Lim Kim Keang, Lim Kim Seng, Low Bing Wen, Alan } \\
\text { Owyong }\end{array}$ \\
\hline $\begin{array}{l}\text { Freshwater } \\
\text { Fish }\end{array}$ & $\begin{array}{l}\text { Cai Yixiong \& Tan Heok } \\
\text { Hui } \\
\text { Coordinator: } \\
\text { Li Tianjiao }\end{array}$ & $\begin{array}{l}\text { Cai Yixiong, Darren. C.J. Yeo, Li Tianjiao, Lim } \\
\text { Weihao, Loh Yu Xuan, Low Bi Wen, Movin } \\
\text { Nyanasengeran, Tan Heok Hui }\end{array}$ \\
\hline
\end{tabular}


Table 1. Continuation.

\begin{tabular}{|c|c|c|}
\hline Topic & $\begin{array}{l}\text { Group planners and } \\
\text { coordinators }\end{array}$ & Researchers (in alphabetical order) \\
\hline $\begin{array}{l}\text { Freshwater } \\
\text { decapod } \\
\text { crustaceans }\end{array}$ & $\begin{array}{l}\text { Cai Yixiong \& Darren Yeo } \\
\text { Coordinators: } \\
\text { Li Tianjiao, Lim Weihao } \\
\text { and Daniel Ng }\end{array}$ & $\begin{array}{l}\text { Cai Yixiong, Daniel J.J. Ng, Darren C.J. Yeo, Li } \\
\text { Tianjiao, Lim Weihao, Max D.Y. Khoo, Movin } \\
\text { Nyanasengeran, Nigel J.L. Tiong }\end{array}$ \\
\hline Butterflies & $\begin{array}{l}\text { Sharon Chan \& Khew Sin } \\
\text { Khoon } \\
\text { Coordinator: } \\
\text { Holly Siow }\end{array}$ & $\begin{array}{l}\text { Chng Chuen Kiong, Foo Jit Leang, Horace Tan, Huang } \\
\text { Caijin, Khew Sin Khoon, Loke Peng Fai, Simon Sng, } \\
\text { Sunny Chir }\end{array}$ \\
\hline Moths & $\begin{array}{l}\text { Lena Chan \& Raymond } \\
\text { Karam } \\
\text { Coordinator: } \\
\text { Zhou Boyi }\end{array}$ & Chong Jun Hien, Henry Barlow, Raymond Karam \\
\hline Stick insects & $\begin{array}{l}\text { Lena Chan \& Francis Seow- } \\
\text { Choen } \\
\text { Coordinator: } \\
\text { Zhou Boyi }\end{array}$ & $\begin{array}{l}\text { Choo Mui Eng, Chua Ee Kiam, Francis Seow-Choen, } \\
\text { Isaac Seow-Choen }\end{array}$ \\
\hline Orthoptera & $\begin{array}{l}\text { Lena Chan \& Tan Ming Kai } \\
\text { Coordinators: } \\
\text { Daniel Ng and Li Tianjiao }\end{array}$ & $\begin{array}{l}\text { Mirza Rifiq bin Ismail, Robin Ngiam Wen Jiang, Tan } \\
\text { Ming Kai }\end{array}$ \\
\hline $\begin{array}{l}\text { Saproxylic } \\
\text { beetles }\end{array}$ & $\begin{array}{l}\text { Lena Chan \& Cheong } \\
\text { Loong Fah } \\
\text { Coordinator: } \\
\text { Geoffrey Davison }\end{array}$ & $\begin{array}{l}\text { Cheong Loong Fah, Robin Ngiam Wen Jiang, Sean } \\
\text { Yap }\end{array}$ \\
\hline Bees & $\begin{array}{l}\text { Lena Chan \& John Ascher } \\
\text { Coordinator: } \\
\text { Zestin Soh }\end{array}$ & $\begin{array}{l}\text { Andrea Leong, Benjamin Ho, Chui Shao Xiong, } \\
\text { Eunice Soh, Foo Mao Sheng, Joey Lai, John Ascher, } \\
\text { John Lee, Rebecca Lee, Zestin Soh }\end{array}$ \\
\hline $\begin{array}{l}\text { Springtail } \\
\text { catchers }\end{array}$ & $\begin{array}{l}\text { Lena Chan \& Patrick } \\
\text { Grootaert } \\
\text { Coordinator: } \\
\text { Daniel Ng }\end{array}$ & $\begin{array}{l}\text { Ang Yuchen, Foo Maosheng, Jonathan Ho Kit Ian, } \\
\text { Patrick Grootaert, Rudolf Meier }\end{array}$ \\
\hline
\end{tabular}


Table 1. Continuation.

\begin{tabular}{|c|c|c|}
\hline Topic & $\begin{array}{l}\text { Group planners and } \\
\text { coordinators }\end{array}$ & Researchers (in alphabetical order) \\
\hline Spiders & $\begin{array}{l}\text { Lena Chan \& Joseph Koh } \\
\text { Coordinators: } \\
\text { Joanna Yeo \& Liew Qi }\end{array}$ & $\begin{array}{l}\text { Alan Tan, Azlin Sani, Chris S.P. Ang, Christina Choy, } \\
\text { David J. Court, Derek Liew, Fiona Loh, James W.B. } \\
\text { Koh, Joanna M.L. Yeo, Joseph K.H. Koh, Joyce Koh, } \\
\text { Justin Tan, Lee Yueying, Lena Chan, Liew Qi, Mark } \\
\text { Wong, Mendis Tan, Peifen P.H. Koh, Rachel Lim, } \\
\text { William Ng }\end{array}$ \\
\hline $\begin{array}{l}\text { Dragonflies } \\
\text { and } \\
\text { damselflies }\end{array}$ & $\begin{array}{l}\text { Cai Yixiong } \\
\text { Coordinator: } \\
\text { Ngiam Wenjiang }\end{array}$ & $\begin{array}{l}\text { Cai Yixiong, Robin Ngiam Wen Jiang, Yvonne P.Q. } \\
\text { Nga }\end{array}$ \\
\hline $\begin{array}{l}\text { Terrestrial } \\
\text { Physical } \\
\text { geography }\end{array}$ & $\begin{array}{l}\text { Sharon Chan \& Kalyani } \\
\text { Chatterjea } \\
\text { Coordinator: } \\
\text { Hassan Ibrahim }\end{array}$ & $\begin{array}{l}\text { Kalyani Chatterjea and many National Institute of } \\
\text { Education's students }\end{array}$ \\
\hline $\begin{array}{l}\text { Freshwater } \\
\text { stream quality }\end{array}$ & $\begin{array}{l}\text { Lena Chan \& Cai Yixiong } \\
\text { Coordinator: } \\
\text { Cai Yixiong }\end{array}$ & $\begin{array}{l}\text { Alan D. Ziegler, Cai Yixiong, Khairun Nisha, Liong } \\
\text { Shie-Yui, Nguyen Canh Tien Trinh }\end{array}$ \\
\hline $\begin{array}{l}\text { Morphology } \\
\text { of streams }\end{array}$ & $\begin{array}{l}\text { Lena Chan \& Cai Yixiong } \\
\text { Coordinator: } \\
\text { Cai Yixiong }\end{array}$ & Cai Yixiong \\
\hline $\begin{array}{l}\text { Genomics of } \\
\text { insects }\end{array}$ & $\begin{array}{l}\text { Lena Chan \& Rudolf Meier } \\
\text { Coordinator: } \\
\text { Li Tianjiao }\end{array}$ & $\begin{array}{l}\text { Fieldwork: Foo Maosheng, Wendy Wang: Pre-sorting } \\
\text { to order: } 5 \text { paid student helpers, DNA and imaging } \\
\text { work: } 2 \text { RAs (Jayanthi and Theo), } 6 \text { RP interns, } 3 \\
\text { Honours students, } 2 \text { casual staff }\end{array}$ \\
\hline
\end{tabular}

a. A map of the nature reserve showing contours, tracks and vegetation types, prepared from datasets commissioned, owned or edited by the National Parks Board, so that all teams would refer to a common map (Fig. 2)

b. The request to give coverage to the various forest zones shown on the map, with suggestions on the trail systems that would give coverage to primary forest (Summit Road, also referred to as Main Road, and Jungle Fall Path), old secondary forest (Catchment Path, South View), and maturing secondary forest (Lasia Track)

c. A grid system of coordinates, so that results from different teams could be compared or integrated in future. (Fig. 3) 


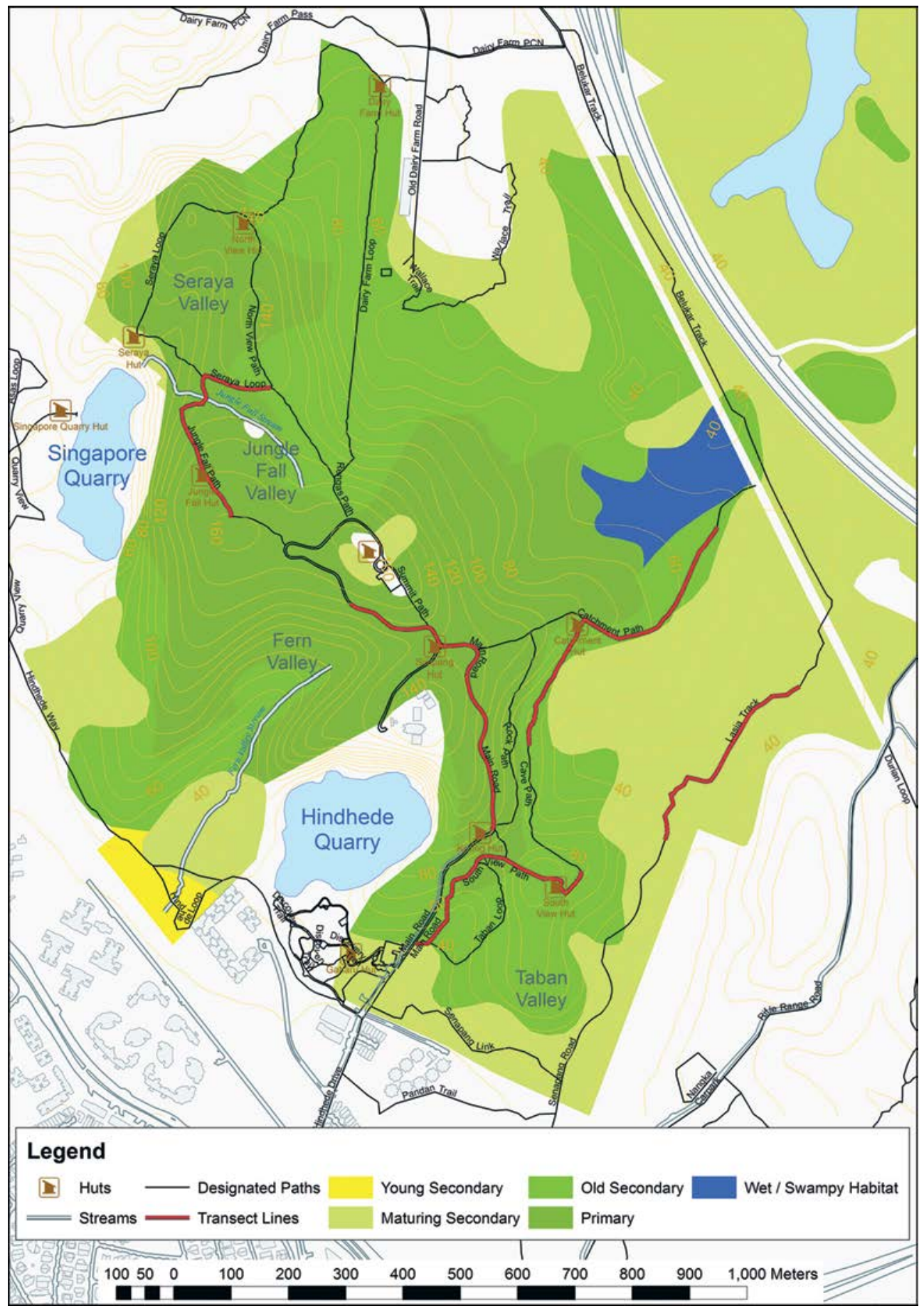

Fig. 2. Map of Bukit Timah Nature Reserve, Singapore, provided to all survey participants as a guide to vegetation zones, suggested survey trails and transects, and place names. (Source: NParks). 
Specific aspects to be included were:

a. What species occur?

b. Where are they found?

c. Can quantitative information be collected?

d. What biological and physical factors are crucial for the long-term survival of species?

Coverage of plant and animal groups was meant to be broad, with as many as possible of the groups surveyed in 1992-1997 being re-surveyed in 2015-2016 using, where possible, similar methods, study locations and personnel. The extent to which this was achieved is summarised in a table by Chan \& Davison (2019). Some groups included in the earlier survey (e.g., aquatic Hemiptera) could not be studied again because experts were no longer available, but other groups were added (e.g., macrofungi, bees, moths, saproxylic beetles, spiders, springtail catchers, orthopterans). There was greater coverage of physical parameters, and some of the information collected spans the entire period between the two main NParks surveys and even before (Cai, 2019; Chatterjea, 2019; Nguyen \& Cai, 2019).

Participants were asked to conduct their studies so as to identify possible differences in the flora, fauna and other characteristics of the three vegetation zones, if any. It was hoped that the value of the results would be increased by using a shared system of trails and vegetation zones.

However, it was recognised that such advantages also imposed constraints on the participants. The availability of paths within each vegetation zone was not equal, and their distribution hindered the use of standard methods, as well as affecting the statistical treatment of results. Less than optimum methods had to be used for some groups, or alternatively the emphasis on the three vegetation zones had to be relaxed.

A further constraint was introduced by the request that participants should, where feasible, make their survey comparable with that done in 1992-1997. It was recognised that these demands were not easy to comply with and participants were free to make compromises.

\section{Output, analyses and conclusions}

The results of the Comprehensive Biodiversity Survey of Bukit Timah Nature Reserve, 2014-2018, are published in this, a supplement to the Gardens' Bulletin, Singapore. The outputs, general analyses and general conclusions are covered by Chan \& Davison (2019). Work on physical geography, visitor impacts and the effectiveness of remediation measures (Chatterjea, 2019), together with the longterm research on forest trees by LaFrankie et al. (2005), provided the terrestrial background for papers on macrofungi by Lee (2019), the flora by Ho et al. (2019), on mammals, amphibians and reptiles by Teo \& Thomas (2019), on birds by Lim (2019), 


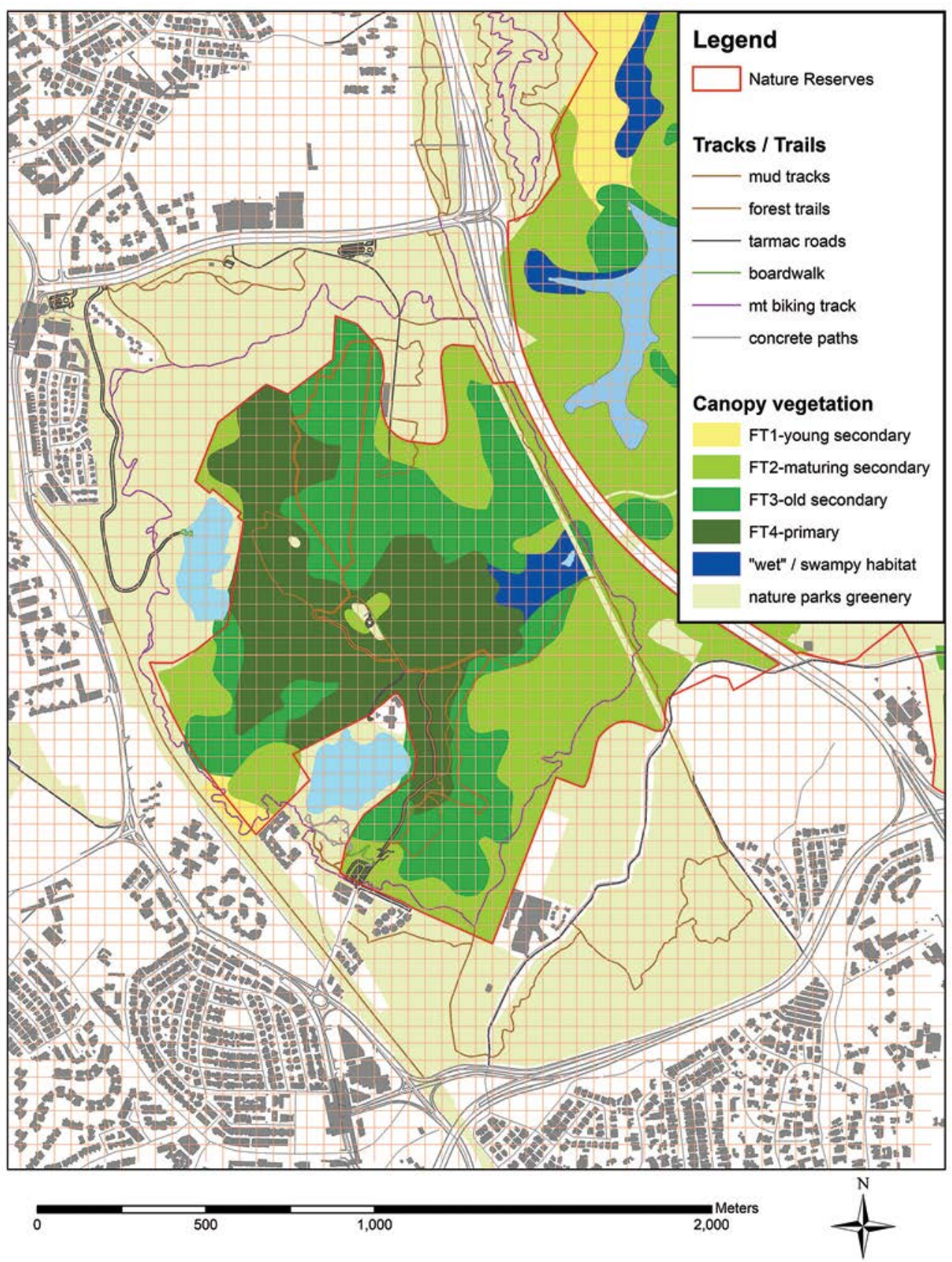

Fig. 3. Map of Bukit Timah Nature Reserve, Singapore, with a grid system of coordinates issued to the researchers so that results from the different teams can be compared and integrated in future (Source: NParks). 
spiders by Koh \& Court (2019), butterflies by Khew \& Tan (2019), moths by Karam \& Chong (2019), bees by Ascher et al. (2019), orthopterans by Tan (2019), stick insects by Seow-Choen et al. (2019), saproxylic beetles by Cheong (2019) and springtail-catching flies by Grootaert \& Foo (2019). A survey of the freshwater environment by Nguyen \& Cai (2019) and Cai (2019) has provided the aquatic background for papers on freshwater decapods by Khoo et al. (2019), fishes by $\mathrm{Li}$ et al. (2019), and dragonflies by Cai et al. (2019). A paper on the use of Next Generation sequencing of the insects found in BTNR (Ho et al. 2019) complements the ecosystem and species approach of this project.

Despite dense urbanisation in the vicinity, and the large numbers of visitors to BTNR, its biodiversity, the discovery of new species, new records and the re-discovery of species previously thought to be locally extinct continue to surprise us. This volume is a celebration of the work of more than 20 Group Planners, ten National Parks Board coordinators, and a conservative estimate of more than 300 researchers and volunteers. Each and every one of them willingly and generously contributed their time to complete the full survey, from planning to fieldwork, photography, preparation of specimens, identification, to the final analysis and documentation of results. The authors of the papers in this volume, their colleagues and volunteers spent many hours and days to make this a scientifically sound and memorable contribution of blood, sweat and tears!

ACKNOWLEDGEMENTS. We would like to thank Mr. Kenneth Er (CEO of the National Parks Board) for his leadership in this scientific survey. The unwavering support and generous assistance of Dr Leong Chee Chiew (Deputy CEO), Sharon Chan (Director, Central Nature Reserves), and staff of the BTNR, in particular, Cheryl Chia, are much appreciated. We thank members of the Nature Reserves Scientific Advisory Committee for their role in advice and planning. The success of the Comprehensive Biodiversity Survey of Bukit Timah Nature Reserve must undoubtedly be attributed to the group planners, coordinators, and the scientists and volunteers who sacrificed much of their time to take part in all of the surveys. They are named in Table 1; we thank them and all authors immensely for the papers that follow. We are thankful for Chew Ping Ting's skilful preparation of the contour map showing trails, water bodies and vegetation zones, on behalf of the National Parks Board. We would especially like to express our gratitude to David Middleton, Lily Chen and Jana Leong- Škorničková and Ada Davis for their meticulous editing. The generous financial and volunteer support of Hongkong and Shanghai Banking Corporation Limited and NParks are gratefully acknowledged.

\section{References}

Ascher, J.S., Soh, Z.W.W., Ho, B.M., Lee, R.Y.Y., Leong, A.Q.E., Chui, S.X., Lai, J.J.L., Lee, J.X.Q., Foo, M.-S. \& Soh, E.J.Y. (2019). Bees of the Bukit Timah Nature Reserve and vicinity. Gard. Bull. Singapore 71 (Suppl. 1): 245-271.

Cai, Y. (2019). Hydrogeomorphic characteristics of streams in Bukit Timah Nature Reserve, Singapore. Gard. Bull. Singapore 71 (Suppl. 1): 441-490. 
Cai, Y., Nga, Y.P.Q. \& Ngiam, R.W.J. (2019). Diversity and distribution of dragonflies in Bukit Timah Nature Reserve, Singapore. Gard. Bull. Singapore 71 (Suppl. 1): 296-316.

Cantley, N. (1883). Report on the Forests of the Straits Settlements. Singapore: Government Printing Office.

Cantley, N. (1885). Report on the Forests of the Straits Settlements. Singapore: Government Printing Office.

Chan, L. \& Corlett, R.T. (eds) (1997). Biodiversity in the Nature Reserves of Singapore. Gard. Bull. Singapore 49(2): 145-425.

Chan, L. \& Davison, G.W.H. (2019). Synthesis of results from the Comprehensive Biodiversity Survey of Bukit Timah Nature Reserve, Singapore, with recommendations for management. Gard. Bull. Singapore 71 (Suppl. 1): 583-610.

Chatterjea, K. (2019). Bukit Timah Nature Reserve: a forest in transition. Gard. Bull. Singapore 71 (Suppl. 1): 419-440.

Cheong, L.F. (2019). Estimating saproxylic beetle (Coleoptera: Cerambycidae and Buprestidae) diversity in Bukit Timah Nature Reserve, Singapore, with a methodological and biological review. Gard. Bull. Singapore 71 (Suppl. 1): 339-368.

Chin, S.C., Corlett, R.T., Wee, Y.C. \& Geh, S.M. (eds) (1995). Rain Forest in the City: Bukit Timah Nature Reserve, Singapore. Gard. Bull. Singapore (Suppl. 3): 1-167.

Chou, L.M. (1995). Amphibians and reptiles. Gard. Bull. Singapore (Suppl. 3): 145-150.

Corlett, R.T. (1995a). Introduction. Gard. Bull. Singapore (Suppl. 3): 1-5.

Corlett, R.T. (1995b). The History of Bukit Timah Nature Reserve. Gard. Bull. Singapore (Suppl. 3): 7-10.

Corlett, R.T. (1995c). Flowering Plants at Bukit Timah. Gard. Bull. Singapore (Suppl. 3): 11-27.

Corlett, R.T. (1995d). The Future of Bukit Timah Nature Reserve. Gard. Bulletin Singapore (Suppl. 3): 165-168.

Corlett, R.T. (1997). The vegetation in the nature reserves of Singapore. Gard. Bull. Singapore 49: $147-159$.

Corlett, R.T. \& Lucas, P.W. (1995). Mammals of Bukit Timah. Gard. Bull. Singapore (Suppl. 3): 93-104.

Grootaert, P. \& Foo, M. (2019). The springtail catchers of the genus Neurigona (Insecta, Diptera, Dolichopodidae) in the old-growth forest of Bukit Timah Nature Reserve, Singapore. Gard. Bull. Singapore 71 (Suppl. 1): 369-379.

Gupta, A. (1992). Physiography of the Bukit Timah Nature Reserve and the Central Water Catchment area: a preliminary report. Unpublished report. Reports on the Nature Reserves Survey (Phase I). National Parks Board, Singapore.

Henderson, J.C. (2000). The survival of a forest fragment: Bukit Timah Nature Reserve, Singapore. In: Font, X. \& Tribe, J. (eds) Forest Tourism and Recreation: Case Studies in Environmental Management, pp. 23-39. Wallingford, United Kingdom: CABI.

Ho, B.C., Lua, H.K., Bazilah Ibrahim, Yeo, R.S.W., Athen, P., Leong, P.K.F., Ali Ibrahim, Koh, S.L., Hassan Ibrahim, Lindsay, S., Chin, L.L., Seah, W.W. \& Middleton, D.J. (2019). The plant diversity in Bukit Timah Nature Reserve, Singapore. Gard. Bull. Singapore 71 (Suppl. 1): 41-134.

Ho, J.K.I., Foo, M., Yeo, D.C.J. \& Meier, R. (2019). The other 99\%: exploring the arthropod species diversity of Bukit Timah Nature Reserve, Singapore. Gard. Bull. Singapore 71 (Suppl. 1): 391-417. 
Kang, N. (1992). The birds and mammals of the Central Catchment area: a preliminary report. Unpublished report. Reports on the Nature Reserves Survey (Phase I). National Parks Board, Singapore.

Kang, N. \& Hails, C.J. (1995). The birds of the Bukit Timah Nature Reserve and Central Catchment Area. Gard. Bull. Singapore (Suppl. 3): 121-143.

Karam, R. \& Chong, J.H. (2019). Moths of Bukit Timah Nature Reserve, Singapore. Gard. Bull. Singapore 71 (Suppl. 1): 317-330.

Khew, S.K. \& Tan, H. (2019). Butterflies of the Bukit Timah Nature Reserve, Singapore, and its vicinity. Gard. Bull. Singapore 71 (Suppl. 1): 273-292.

Khoo, M.D.Y., Tiong, N.J.L., Li, T., Lim, W., Ng, D.J.J., Nyanasengeran, M., Yeo, D.C.J. \& Cai, Y. (2019). The freshwater decapod crustaceans of Bukit Timah Nature Reserve, Singapore. Gard. Bull. Singapore 71 (Suppl. 1): 575-581.

Koh, J.K.H. \& Court, D.J. (2019). Spider diversity in the Bukit Timah Nature Reserve, Singapore. Gard. Bull. Singapore 71 (Suppl. 1): 209-243.

LaFrankie, J., Davies, S.J., Wang, L.K., Lee, S.K. \& Lum, S.K.Y. (2005). Forest Trees of Bukit Timah. Population ecology in a tropical forest fragment. Singapore: Simply Green.

Lee, S.M.L. (2019). Macro-fungal diversity of Bukit Timah Nature Reserve, Singapore. Gard. Bull. Singapore 71 (Suppl. 1): 135-144.

Li, T.J., Loh, Y. X., Lim, W.H., Nyanasengeran, M., Low, B.W., Tan, H.H., Yeo, D. C. J. \& Cai, Y. (2019). The fish fauna of Bukit Timah Nature Reserve, Singapore. Gard. Bull. Singapore 71 (Suppl. 1): 557-573.

Lim, K.K.P. (1995). Fishes. Gard. Bull. Singapore (Suppl. 3): 159-163.

Lim, K.S. (2019). Birds of Bukit Timah Nature Reserve, Singapore. Gard. Bull. Singapore 71 (Suppl. 1): 185-208.

Louis, I. (1995). Vesicular-arbuscular mycorrhizae. Gard. Bull. Singapore (Suppl. 3): 81-92.

Lucas, P.W. (1995). Long-tailed Macaques. Gard. Bull. Singapore (Suppl. 3): 105-119.

Lum, S. \& Sharp, I. (eds) (1996). A View from the Summit. The story of Bukit Timah Nature Reserve. Singapore: Nanyang Technological University, National University of Singapore and National Parks Board.

Metcalfe, D.J., Grubb, P.J. \& Turner, I.M. (1998). The ecology of very small-seeded shade-tolerant trees and shrubs in lowland rain forest in Singapore. Pl. Ecol. 134: $131-149$.

Murphy, D.H. (1993). On preparatory work towards a survey of the invertebrate animal life of the Central Catchment Nature Reserves in Singapore. Interim Report, part 1 and 2. Unpublished reports on the Nature Reserves Survey (Phase I). National Parks Board, Singapore.

Ng, P.K.L. (1995). Freshwater decapod crustaceans. Gard. Bull. Singapore (Suppl. 3): $151-157$.

Nguyen, C.T.T. \& Cai, Y. (2019). Physicochemical characteristics of streams in Bukit Timah Nature Reserve, Singapore. Gard. Bull. Singapore 71 (Suppl. 1): 491-556.

Seow-Choen, F., Seow-En, I., Chua, E.K. \& Choo, M.E. (2019). A survey of stick-insects in Bukit Timah Nature Reserve, Singapore. Gard. Bull. Singapore 71 (Suppl. 1): 381-389.

Tan, H.T.W., Chua, K.S. \& Turner, I.M. (1995). Rubiaceae of the Bukit Timah Reserve. Gard. Bull. Singapore (Suppl. 3): 23-59.

Tan, M.K. (2019). Orthoptera species checklist of Bukit Timah Nature Reserve in the Zoological Reference Collection, Singapore. Gard. Bull. Singapore 71 (Suppl. 1): $331-338$. 
Teo, R.C.H. \& Thomas, N.J. (2019). Updated inventory of the amphibians, reptiles and mammals of Bukit Timah Nature Reserve, Singapore. Gard. Bull. Singapore 71 (Suppl. 1): 135-144.

Turner, I.M., Tan, H.T.W. \& Chua, K.S. (1992). A botanical survey of the Nature Reserves. Unpublished report. Reports on the Nature Reserves Survey (Phase I). National Parks Board, Singapore.

Wallace, A.R. (1869). The Malay Archipelago: the land of the orang-utan and the bird of paradise. A narrative of travel with studies of man and nature, vol. 1. London: Macmillan and Co.

Wallace, A.R. (1876). The geographical distribution of animals, with a study of the relations of living and extinct faunas as elucidating the past changes of the earth's surface. London: Macmillan and Co.

Wee, Y.C. (1964). A note on the vegetation of Singapore island. Malayan Forester 27: 257-266.

Wee, Y.C. (1995a). Pteridophytes. Gard. Bull. Singapore (Suppl. 3): 61-69.

Wee, Y.C. (1995b). Algae. Gard. Bull. Singapore (Suppl. 3): 77-80.

Wee, Y.C. \& Mohamed, H. (1995). Bryophytes. Gard. Bull. Singapore (Suppl. 3): 71-76.

Wong, Y.K., Chew, P.T. \& Ali Ibrahim (1994). The tree communities of the Central Catchment Nature Reserve, Singapore. Gard. Bull. Singapore 46: 37-78.

Yang, C.M., Lim, K.K.P., Lua, H.K. \& Yeo, K.L. (1992). A report on the preliminary Nature Reserves survey of insects, amphibians and reptiles of the Central Catchment area. Unpublished report. Reports on the Nature Reserves Survey (Phase I). National Parks Board, Singapore. 